\title{
JEJAK ORGANISASI ASRAMA RATNANINGSIH: DIGITALISASI SEBAGAI UPAYA PENYELAMATAN ARSIP
}

\author{
Arif Rahman Bramantya \\ Program Studi Kearsipan, Sekolah Vokasi, Universitas Gadjah Mada \\ arif.rahman.b@mail.ugm.ac.id
}

\begin{abstract}
Ratnaningsih dormitory is a female student dormitory founded by UGM Women's Family Association (PWK UGM) with a capacity of 90 peoples in the 1960s. At that time, Ratnaningsih dormitory was very helpful for the students as a result of large amount of the students studying at UGM. Through the organization of the Family of Ratnaningsih Female Student Dormitory (KAMPR), various activities are recorded and documented. Along the time, KAMPR began to fade away and disperse, thus the archives was not maintained and it's almost lost. One of the saved collection of KAMPR refers to organization's photographs archive. In archival management, the photographs archive included in audiovisual form and it's required a contextual approach to be descripted in accordance with international standards. Specifically, this study explains the importance of archives for human life and historical consciousness of the students about KAMPR activities through the students learning process of photographs archive management as a non credits practice. The process of digitilalization becomes an important part in the maintain and preservation of photographs archive. Eventually, (virtual) exhibitions is one of the media socialization as an educational tool that can increase public conciousness in the era of information technology.
\end{abstract}

Keywords : KAMPR, photographs archive, historical consciousness, digitalization, exhibitions

\section{Intisari}

Asrama Ratnaningsih adalah asrama mahasiswa putri yang didirikan oleh Persatuan Wanita Keluarga UGM (PWK UGM) dengan kapasitas 90 orang di tahun 1960an. Pada saat itu, asrama Ratnaningsih sangat membantu para mahasiswa sebagai akibat dari banyaknya mahasiswa yang belajar di UGM. Melalui organisasi Keluarga Asrama Mahasiswa Ratnaningsih (KAMPR), berbagai kegiatan organisasi direkam dan didokumentasikan. Dengan berjalannya waktu, KAMPR mulai memudar dan membubarkan diri, oleh karena itu arsipnya tidak terawat dan hampir hilang. Salah satu koleksi KAMPR yang tersimpan mengacu pada arsip foto organisasi. Dalam pengelolaan arsip, arsip foto termasuk dalam bentuk audiovisual dan diperlukan pendekatan kontekstual untuk dapat dideskripsi sesuai dengan standar internasional. Secara khusus, penelitian ini menjelaskan pentingnya arsip bagi kehidupan manusia dan kesadaran sejarah tentang kegiatan KAMPR melalui proses pembelajaran mahasiswa dalam pengelolaan arsip foto sebagai bentuk praktik non SKS. Proses digitalisasi menjadi bagian penting dalam pemeliharaan dan pelestarian arsip foto. Pada akhirnya, pameran (virtual) merupakan salah satu media sosialisasi sebagai alat edukasi yang dapat meningkatkan kesadaran masyarakat di era teknologi informasi.

Kata kunci: KAMPR, arsip foto, kesadaran sejarah, digitalisasi, pameran 


\section{PENDAHULUAN}

Hari Kearsipan Nasional ke-46 jatuh pada tanggal 18 Mei 2017. Diketahui bahwa tanggal 18 Mei merupakan tanggal pengesahan Undang-Undang No. 7 tahun 1971 tentang Ketentuan-ketentuan Pokok Kearsipan yang kemudian diganti dengan Undang-Undang No. 43 Tahun 2009 tentang Kearsipan karena dianggap perlu penyesuaian dengan kebutuhan kehidupan bermasyarakat, berbangsa, dan bernegara yang dipengaruhi oleh perkembangan nasional dan global serta perkembangan teknologi informasi dan komunikasi. Tanggal 18 Mei pun menjadi tanggal yang memiliki nilai kesejarahan, sekaligus menjadi tonggak politik bahwa bidang kearsipan memiliki aspek yang fundamental dalam kehidupan bermasyarakat, berbangsa dan bernegara. Slogan bertajuk "Tertib Arsip Cermin Budaya bangsa" dalam peringatan hari Kearsipan Nasional ke-46, bukan sekedar slogan, melainkan esensi dari slogan tersebut harus mengakar pada masyarakat agar Gerakan Nasional Sadar Tertib Arsip (GNSTA)) dapat terwujud (Surat Edaran Kepala ANRI Nomor 1 Tahun 2017). Namun realita sosial yang sering dijumpai bahwa masih banyak masyarakat yang belum sadar pentingnya arsip bagi kehidupan.

"Sekitar akhir 2011, saya bertemu dengan adik angkatan di Asrama Putri Ratnaningsih UGM (asrama RN), yang mengabarkan bahwa koleksi perpustakaan Asrama RN akan dihibahkan ke Perpustakaan Kota Yogyakarta dikarenakan pengelola Asrama yang sudah berubah. Organisasi Keluarga Asrama Mahasiswa Ratnaningsih (KAMPR) yang mengelola perpustakaan Asrama pun sudah tidak ada karena telah membubarkan diri. Saya tentu saja kaget luar biasa. Sebagai salah satu alumni asrama tersebut saya tentunya menyayangkan keputusan itu, sebab koleksi perpustakaan yang terdiri dari buku, novel, majalah, termasuk juga catatan-catatan kegiatan keorganisasian Asrama RN, foto-foto kegiatan, laporan-laporan kegiatan asrama RN yang telah didirikan sejak 1954 itu, jika dihibahkan ke perpustakaan Kota Yogyakarta tentunya seluruh jejak perjalanan Asrama RN akan turut hilang" (Mariana, 2014, p. 76)

Anna Mariana adalah alumni asrama Ratnaningsih, seorang peneliti sekaligus pengelola Etnohistori ${ }^{1}$ menganggap bahwa beberapa koleksi perpustakaan asrama Ratnaningsih perlu dikelola dan ditata agar sumber informasi yang terdapat didalamnya dapat bernilai guna khususnya bagi kepentingan akademis. Melalui serangkaian korespondensi yang dilakukannya, beberapa koleksi kegiatan Organisasi Keluarga Asrama Mahasiswa Ratnaningsih (KAMPR) yang berhasil diselamatkan antara lain majalah, novel populer, laporan-laporan, buku, kliping dan dokumentasi kegiatan berupa foto. Pengurus Organisasi Keluarga Asrama Mahasiswa Ratnaningsih menyerahkan koleksi asrama kepada Etnohistori di tahun 2012. Menurut Anna, salah satu sebab tidak terawatnya koleksi asrama Ratnaningsih sejak tahun 2008 adalah proses regenerasi pengurus yang dihentikan secara halus dan terhambatnya diseminasi pengetahuan tentang kepengurusan organisasi kepada warga baru. ${ }^{2}$ Sangat disayangkan jika

${ }^{1}$ Etnohistori merupakan kelompok kerja kolektif yang berbentuk koperasi dan memiliki fokus terhadap kajian antropologi dan sejarah Indonesia, berbasis penelitian lapangan, publikasi dan advokasi masyarakat. Kelompok kerja ini memperkenalkan serta mempraktikkan etnografi dan historiografi dengan memberikan materi sejarah alternatif dan metode penelitian pada khalayak. www.etnohistori.org

2 Wawancara Anna Mariana dengan Elok Angraeni dan Windi Wahyu Ningtyas (alumni 
jejak perjalanan organisasi asrama Ratnaningsih hilang, maka dapat dipastikan bahwa secuil sejarah perkembangan UGM sebagai universitas tertua pun turut hilang, kerena secara tidak langsung asrama Ratnaningsih telah menjadi bagian dari UGM.

Di sisi lain, konsep creation dalam life cycle record terkait pengertian arsip dapat digolongkan menjadi dua yakni pencipta arsip lembaga dan pencipta arsip perseorangan. Dalam UndangUndang Kearsipan disebutkan bahwa arsip merupakan rekaman kegiatan atau peristiwa dalam berbagai bentuk dan media sesuai dengan perkembangan teknologi informasi dan komunikasi yang dibuat dan diterima oleh lembaga negara, pemerintahan daerah, lembaga pendidikan, perusahaan, organisasi politik, organisasi kemasyarakatan, dan perseorangan dalam pelaksanaan kehidupan bermasyarakat, berbangsa, dan bernegara (Undang-Undang Nomor 43 Tahun 2009 tentang Kearsipan).

Jika ditinjau lebih lanjut dari pengertian arsip tersebut, Organisasi Keluarga Asrama Mahasiswa Ratnaningsih termasuk dalam organisasi kelembagaan pencipta arsip. Semua rekaman kegiatan harus dikelola dengan baik dan benar sesuai dengan kaidah dalam kearsipan. Hasil dokumentasi dan pengelolaan koleksi asrama Ratnaningsih sebelum tahun 2008 oleh Organisasi Keluarga Asrama Mahasiswa Ratnaningsih (KAMPR) tidak terlepas dari rangkaian proses pendisiplinan tubuh sebagai manifestasi gerakan sadar arsip dan kerja pengarsipan sebuah organisasi.

asrama Ratnaningsih) tanggal 12 dan 14 Oktober 2011, via Anna Mariana, "Menghidupkan Arsip, Mencipta Wacana. Pentingnya Arsip Untuk Gerakan Sosial" dalam Farah Wardani dan Yoshi fajar Kresno Murti. Arsipelago, Kerja Arsip dan Pengarsipan Seni Budaya di Indonesia. Yogyakarta: Indonesia Visual Art Archive (IVAA), 2014. Hal. 76.
Tahun 2008, di samping tidak terawatnya koleksi asrama Ratnaningsih, pemahaman arsip sebagai tumpukan kertas (arsip konvensional) masih menjadi kultur masyarakat Indonesia. Apalagi pandangan mengenai arsip yang dianggap hanya dimiliki oleh lembaga resmi pemerintahan, sehingga rujukan para peneliti atau sejarawan seolah-olah hanya berada di lembaga pemerintahan. Selain itu pemahaman jenis arsip lainnya pun masih terbilang minim. Arsip foto misalnya, arsip foto merupakan salah satu arsip bentuk khusus (Records in Special Format) yang sebagian besar menjadi bagian tidak terpisahkan dari arsip tekstual.

Konsep Records in Special Format merupakan arsip yang memiliki informasi terekam dalam bentuk dan karekteristik khusus selain media tekstual atau kertas. Arsip bentuk khusus terdiri dari arsip audiovisual, kartografi dan kearsitekturan, ephemera, karya seni dan arsip elektronik. Dalam hal ini, arsip foto termasuk dalam arsip audiovisual. (Robert, 1993, p.386-389)

Foto merupakan citra diam yang tercipta dari sebuah pengambilan gambar dengan menggunakan kamera. Sedangkan arsip foto merupakan arsip yang isi informasinya berupa gambar statik yang penciptaannya menggunakan peralatan khusus (Peraturan Kepala ANRI Nomor 23 Tahun 2011). Beragam bentuk arsip foto berupa negatif film, hasil cetak, foto digital menjadi bagian yang tidak dapat dipisahkan dari keberadaan jenis arsip lain (arsip konvensional). Pada dasarnya, arsip foto akan menjadi sumber sejarah setelah arsip foto tersebut diciptakan. Beragam nilai informasi yang terkandung di dalam arsip foto dapat digunakan sebagai bahan pembuktian. Peneliti atau sejarawan memanfaatkan arsip foto untuk merangkai sebuah fakta atau peristiwa yang terjadi di masa lampau. Selain itu, perkembangan Etnofotografi untuk 
meneliti sejarah perkembangan kebudayaan manusia pun menggunakan media foto. Penyelenggaraan pameran arsip pun sebagian besar menggunakan material foto.

Permasalahan klasik dan mendasar terhadap pengelolaan arsip foto mengacu pada rendahnya pengetahuan arsiparis terhadap penilaian sebuah foto. Tidak jarang dalam proses penilaian secara subjektif, lembaga yang satu menganggap bahwa arsip foto A misalnya bernilai tinggi dan dianggap penting. Tidak jarang pula lembaga lainnya menganggap foto $\mathrm{A}$ tidak bernilai. Penilaian terhadap foto mengacu pada beberapa faktor, antara lain subjek, umur, keunikan, kualitas, identifikasi, jumlah dan sumber (Roberts, 1993).

Koleksi foto asrama Ratnaningsih yang disimpan oleh Etnohistori kemudian dijadikan pembelajaran bagi para mahasiswa Program Studi Kearsipan melalui kegiatan praktikum. Melalui kerja kolektif, para mahasiswa dituntut untuk dapat mengolah koleksi foto asrama Ratnaningsih dengan baik dan benar. Tidak hanya mengacu pada kepentingan praktis, para mahasiswa pun diajak untuk membangun pribadi yang kritis dan bertanggung jawab serta memiliki kesadaran sejarah bahwa upaya "penghilangan" jejak yang terjadi pada organisasi asrama Ratnaningsih dapat dijadikan pembelajaran. Berdasarkan latar belakang di atas, pokok permasalahan dalam studi ini mengacu pada bagaimana proses mengolah arsip foto koleksi asrama Ratnaningsih dan metode apa yang dipakai untuk menyelamatkan arsip foto. Bagaimana sosialisasi untuk menciptakan sebuah wacana gerakan sosial.

Studi ini menggunakan pendekatan deskriptif. Metode yang dipakai adalah studi pustaka dan observasi. Observasi dilaksanakan dengan cara terlibat langsung dalam proses pengolahan arsip foto bersama dengan para mahasiswa dengan tujuan untuk mendapatkan data dan informasi langsung tentang jejak asrama Ratnaningsih dan proses pembelajarannya. Sedangkan, studi kepustakaan mengacu pada buku-buku, dan artikel tentang pengolahan arsip foto. Melalui pendekatan deskriptif diharapkan mampu menggambarkan kajian akademis yang dapat menjawab permasalahan.

\section{HASIL DAN PEMBAHASAN \\ Asrama Ratnaningsih dan Nilai Kesejarahan}

Pendirian asrama-asrama di UGM tidak terlepas dari Persatuan Wanita Keluarga UGM (PWK UGM), organisasi wanita yang berdiri pada tanggal 30 Januari 1951. Sejak awal perkembangan UGM, organisasi PWK diprakarsai oleh sekelompok ibu istri dosen UGM antara lain Ibu Sardjito, Ibu A. Sigit, Ibu Soedomo, Ibu Hardjono, Ibu Wreksodiningrat, Ibu Djojdigoeno dan Ibu Notosoesanto. ${ }^{3}$ Tujuan utama dari organisasi ini adalah mempererat hubungan antara para wanita keluarga di lingkungan UGM dan memberikan bantuan bila perlu kepada perkembangan UGM di luar pengajaran formal. Organisasi PWK UGM memiliki bagian atau divisi antara lain;

1. Bagian Ekonomi dan Arisan

2. Bagian Pelajaran dan Demonstrasi

3. Bagian Perpustakaan

4. Bagian Sosial ke Dalam

5. Bagian Sosial ke Luar

6. Bagian Asrama Mahasiswa.

${ }^{3}$ Ibu Sardjito merupakan istri Prof. Dr. M. Sardjito (Rektor UGM ke-1), Ibu A.Sigit merupakan istri Prof. Drs. A. Sigit (Guru Besar dan Ketua Fakultit Sastra, Pedagogik, dan Filsafat), Ibu Soedomo merupakan istri Prof. drg. Soedomo (Guru Besar Fakultas Kedokteran Gigi), Ibu Wreksodiningrat merupakan istri Prof. Ir. Wreksodiningrat (Guru Besar Fakultas Teknik UGM, dekan 1947-1951 dan merupakan insinyur teknik sipil pertama Indonesia). 
Tahun 1951, seiring dengan perkembangan UGM yang semakin kokoh, para mahasiswa terus bertambah sedangkan mereka kesulitan untuk mencari pondokan. Pada bulan Desember 1951, UGM mendirikan 24 buah asrama. Kurang lebih 13 tahun kemudian, tidak berselang lama, dua asrama besar berhasil didirikan yakni asrama Dharma Putra untuk mahasiswa dan asrama Ratnaningsih untuk mahasiswi (Agustina, 2013, p.37).

Asrama Ratnaningsih memiliki organisasi tersendiri bernama organisasi Keluarga Asrama Mahasiswa Putri Ratnaningsih (KAMPR). Sebagai sebuah organisasi, mereka menghasikan arsip yang menjadikan kepengurusan organisasi tersebut bertahan lama. Kerja dokumentasi dan pengarsipan oleh organisasi asrama menurut Anna Mariana terbilang baik, arsip yang dimiliki asrama Ratnaningsih terdiri dari foto-foto kegiatan organisasi asrama tahun 1970-an-2000-an, laporan kegiatan organisasi, proposal kegiatan kerjasama dan lain-lain. Di tahun 2008, hasil kerja dokumentasi dan kerja pengarsipan organisasi dapat dikatakan tidak terawat, bahkan organisasi tersebut hilang seiring dengan berjalannya waktu.

Terkait dengan perjalanan sejarah organisasi Keluarga Asrama Mahasiswa Putri Ratnaningsih (KAMPR), menghidupkan ingatan kolektif merupakan sesuatu hal yang tidak mudah. Selain dibutuhkan data-data primer untuk membangun peristiwa sejarah, konteks sejarah kritis dalam metode penelitian sejarah tidak dapat dikesampingkan. Berangkat dari kegelisahan mengenai kurangnya kesadaran akan pentingnya arsip dan kesadaran akan sejarah tentang aktivitas asrama Ratnaningsih sebagai bagian yang tidak dapat dipisahkan dari Universitas Gadjah Mada, rekonstruksi historis diharapkan dapat membangun pemahaman menyeluruh. Cara pandang terhadap arsip dan menghidupkannya melalui proses kreatif akan membentuk narasi sejarah dengan gaya tersendiri. Pada akhirnya proses ini akan membentuk wacana lain untuk membuat sebuah gerakan sosial di dalam masyarakat. Membaca khazanah asrama Ratnaningsih sebagai sebuah gerakan perempuan bercorak asrama dengan segala aktivisme di dalamnya setidaknya menjadi dasar bahwa nilai kesejarahan dalam arsip dapat menjadi sumber informasi yang bernilai guna akademis (Mariana, 2014).

Pengguna akan tergantung pada sumber informasi di dalam arsip. Arsip akan tersedia dan "hidup" jika ada yang seseorang yang ahli dalam menanganinya. Arsiparis bertugas untuk menyiapkan, menata, menyimpan dan mengolah agar sumber data tersebut dapat disajikan dan dapat dimanfaatkan oleh pengguna. Sebagai contoh sejarawan (pengguna) memiliki kepentingan untuk menyajikan fakta ke dalam bentuk tulisan sejarah. Kepentingan pengguna satu dengan pengguna lain tentu saja berbeda, namun tetap bermuara pada kepentingan untuk mencari informasi. Dua kepentingan yang berbeda akan menimbulkan simbiosis dan saling melengkapi. Kerja arsiparis pun dituntut untuk memiliki kesadaran yang tinggi akan nilai kesejarahan pada arsip (Bramantya, 2016, p. 9-11). Kesadaran sejarah adalah akumulasi pengetahuan tentang fakta-fakta sejarah beserta sebab akibatnya dan meningkatkan alam pikiran dengan logika serta peningkatan hati nurani dengan hikmah kearifan dan kebijaksanaan untuk menghadapi masa sekarang dan masa depan dengan belajar dan bercermin kepada pengalamanpengalaman masa lalu (Abdulgani, 1980, p. 10-11). 


\section{Pengolahan Foto Organisasi Asrama Ratnaningsih sebagai Media Pembelajaran Mahasiswa}

Menilik perkembangan dunia fotografi diawali dengan ditemukannya teknologi kamera oleh Jaques Daguerre tahun 1837. Sejarah di Hindia-Belanda menyebutkan bahwa kegiatan berfoto pada saat itu sebagian besar hanya dilakukan oleh para bangsawan. Fotofoto pada era ini untuk menunjukkan status sosial. Di sisi lain, fakta sejarah menyebutkan bahwa di era kemerdekaan peristiwa bersejarah berhasil diabadikan oleh Frans dan Alex Mendur. Dengan penuh perjuangan, menghindar dari kejaran tentara Jepang sampai harus menyembunyikan negatif foto ke dalam tanah, mereka berhasil mencetak foto detik-detik Proklamasi yang sampai saat ini dapat dijumpai dalam buku-buku sejarah Indonesia. Tulisan di atas menjadi paragraf awal untuk menggambarkan bahwa foto yang bernilai sejatinya harus dirawat dan dilestarikan, bukan "dihilangkan" seperti dalam kasus asrama Ratnaningsih hanya karena persoalan teknis, tidak ada yang memberdayakan koleksi asrama maupun tidak ada ketertarikan terhadap koleksi tersebut.

Berawal dari korespondensi dengan pengelola Etnohistori, sebagian koleksi foto kegiatan organisasi Keluarga Asrama Mahasiswa Putri Ratnaningsih (KAMPR) yang terselamatkan mendapat perhatian untuk dirawat dan dilestarikan. Kerjasama kelompok yang melibatkan beberapa mahasiswa Program Studi Kearsipan, Sekolah Vokasi, UGM untuk melakukan kerja pengarsipan koleksi foto asrama Ratnaningsih dibentuk. Kelompok mahasiswa menjadikan program ini sebagai kegiatan praktikum non SKS di luar mata kuliah.

Dalam mengolah koleksi foto Ratnaningsih, tidak semua foto memiliki nilai kesejarahan. Nilai informasional dari sebuah foto menjadi aspek penting. Pemahaman terhadap dunia fotografi, orang-orang penting dan peristiwaperistiwa penting terhadap sebuah foto harus dimiliki oleh seorang arsiparis, tentu dengan pendampingan dari supervisor. Selain itu, dalam pengelolaan arsip foto, prinsip Provenance (asal-usul) dan Original Order (aturan asli) dalam pengolahan arsip tidak dapat dikesampingkan.

Prinsip provenance merupakan prinsip yang mengacu pada organisasi pencipta arsip dan fungsi-fungsi di dalam organisasi. Prinsip ini mengacu pada tugas pokok dan fungsi organisasi yang diimplematasikan ke dalam struktur organisasi. Pemahaman dasar mengenai organisasi pencipta yang meliputi tugas pokok dan fungsi menjadi mutlak untuk dipahami. Konteks hubungan arsip foto dengan organisasi pencipta arsip sangat berkaitan dengan prinsip provenance yang menitikberatkan pada konteks fungsi organisasi. Dalam deskripsi arsip foto, pengetahuan tentang latar belakang penciptaan arsip foto yang mencakup tujuan penciptaan arsip foto bagi organisasi pencipta merupakan hal yang sangat penting. Pada dasarnya, setiap organisasi memiliki tugas pokok dan fungsi dalam melaksanakan peran sesuai dengan kedudukannya. Fungsi organisasi ini kemudian dilaksanakan melalui berbagai kegiatan yang dilakukan oleh organisasi. Kegiatan inilah yang direkam atau didokumentasikan dalam bentuk arsip yang salah satunya berbentuk foto.

Prinsip original order adalah penataan arsip yang mengacu pada aturan asli yang digunakan oleh organisasi pencipta arsip. Prinsip ini menekankan bahwa arsip diatur sesuai dengan pengaturan yang dilakukan pada saat arsip masih bersifat dinamis. Arsip foto tidak akan kehilangan konteks administratif yang menjelaskan hubungan arsip foto dengan organisasi pencipta. Penataan arsip foto di organisasi pencipta dilakukan berdasarkan kurun waktu penciptaan foto yang mengacu pada waktu 
pengambilan gambar suatu kegiatan atau peristiwa. Dengan demikian, biasanya arsip foto tersebut tersusun secara kronologis (Pambudi, 2009, p. 43-44).

Tahapan pengelolaan arsip foto dalam ranah seleksi dan penilaian menjadi aspek penting dalam keseluruhan tahapan pengelolaan arsip foto. Seleksi dan penilaian arsip foto merupakan pekerjaan yang paling sulit selain melibatkan aspek pengalaman dan ketrampilan juga melibatkan pemahaman akan sejarah. Seleksi dan penilaian terhadap arsip foto mengacu pada aspek bersifat teknis dan intelektual. Indikator dalam seleksi dan penilaian arsip foto mengacu pada beberapa kategori antara lain pentingnya arsip foto ketika masih dinamis, kuantitas, keunikan, usia arsip foto, jenis media cetak, kualitas fisik, rentang waktu, kegunaan dan aksesbilitas.

Setelah dilakukan proses seleksi tahap awal, kurang lebih 3\% dari total foto dalam kondisi kurang baik. Penyimpanan foto dalam album akan memperpendek usia foto dan menyebabkan foto menjadi rusak. Penyimpanan tanpa sirkulasi udara menyebabkan foto menjadi gelap, pudar dan timbul noda. Penanganan arsip foto berbeda dengan penanganan arsip tekstual. Foto seharusnya disimpan dalam tempat penyimpanan yang memiliki keasaman 6,5-7,5, memiliki alpha selulosa di atas $87 \%$, memiliki kandungan yang dapat mengurangi sulfur dan bebas partikel metal ataupun perekat. Foto sebaiknya ditempatkan dalam bok sesuai standar penyimpanan. Selain itu faktor perusak ekstern seperti suhu udara, kelembaban, cahaya, jamur dan serangga mempengaruhi kondisi foto (Harisson, 1997, p. 300-301). Kontrol terhadap lingkungan yang menyebabkan kerusakan pada foto seperti pertumbuhan jamur, karat, penguningan menjadi penting. Kelembaban relatif atau relative humidity dianjurkan kurang lebih 40\% (Hendriks, 1984).
Kerja pengarsipan yang dilakukan oleh kelompok mahasiswa Program Studi Kearsipan selama kurang lebih 2 bulan dengan beragam koleksi foto kegiatan asrama Ratnaningsih sedikit menemui hambatan. Tidak adanya pengelolaan arsip foto dengan benar, menyebabkan dalam satu album terdapat beberapa foto yang tidak saling berkaitan satu sama lain. Penataan arsip foto asrama Ratnaningsih berdasarkan subyek atau masalah karena sebagian besar album foto mencantumkan informasi mengenai kegiatan atau peristiwa disertai dengan caption dan tanggal kegiatan. Dalam konteks pembelajaran mahasiswa, kerja pengarsipan terkait dengan intellectual handling yang dimiliki individu pun berbeda. Salah satu contoh yang menyebabkan kesalahan tafsir dalam menata arsip foto asrama Ratnaningsih adalah kemampuan identifikasi personal tokoh. Sebagai contoh, mahasiswa tidak mengenal petinggi UGM, seperti Prof. Dr. Ir. Mochamad Adnan, M.Sc, rektor UGM periode 1990-1994. Oleh karena itu, bekal kemampuan dalam mengindentifikasi foto secara eksplisit dikaitkan dengan pemahaman masa lalu, dalam hal ini pemahaman sejarah menjadi penting.

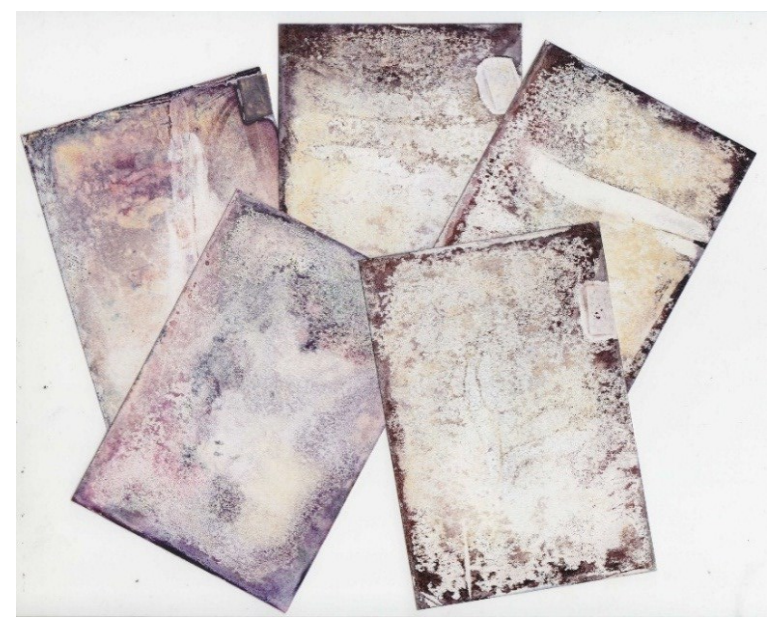

Gambar 1. Foto Koleksi Asrama Ratnaningsih dalam Kondisi Rusak Sumber: Dokumentasi Personal 
Pencarian informasi tentang konteks kegiatan atau peristiwa yang terekam dalam arsip foto asrama Ratnaningsih yaitu dengan cara mempertimbangkan hubungan antara arsip foto satu dan yang lainnya. Oleh karena itu, konteks kegiatan atau peristiwa dalam arsip foto menjadi penting. Informasi secara lengkap dan utuh hanya dapat digambarkan melalui beberapa foto dengan rangkaian cerita dalam gambar.

Penyusunan deskripsi dalam arsip foto berdasar pada General International Standar Archival Description (ISAD-G) di level item yaitu, deskripsi yang memuat keterangan gambar dari masing-masing lembar arsip foto (caption). Proses identifikasi terkait dengan informasi yang didapat pada sebuah foto meliputi subjek, tanggal, tempat, fotografer. Kesulitan untuk mengidentifikasi informasi tentang fotografer sebagian besar dialami oleh para mahasiswa dalam mengolah foto Asrama ratnaningsih. Foto kegiatan asrama Ratnaningsih berukuran 3R berwarna dan satu album foto 3R hitam putih. Tahun tertua yang dapat diidentifikasi yaitu tahun 1970 tentang Peringatan Hari Kartini. Informasi tentang peristiwa atau kegiatan organisasi Keluarga Asrama Mahasiswa Putri Ratnaningsih (KAMPR) ditunjukkan melalui keterangan yang terdapat di album foto. Beberapa kegiatan organisasi asrama Ratnaningsih yang dapat diidentifikasi yaitu
1. Malam Keakraban
2. Forum Nasional
3. Dies Natalis
4. Peringatan Hari Kartini
5. Pelantikan Pengurus KAMPR
6. Perayaan Natal
7. Studi Banding
8. Bakti Sosial
9. Orientasi Warga Baru
10. Perlombaan

Dalam proses pengolahan arsip foto kegiatan organisasi Keluarga Asrama Mahasiswa Putri Ratnaningsih (KAMPR) sebagai bentuk pembelajaran mahasiswa, upaya penyelamatan koleksi foto mengacu pada proses digitalisasi dan eksibisi. Digitalisasi menjadi pembelajaran akhir para mahasiswa agar mereka paham bahwa proses digitalisasi merupakan salah satu rangkaian kegiatan dalam merawat dan melestarikan arsip. Dengan kata lain, melestarikan informasi digital sebagai sumber otentik dalam berbagai kehidupan bermasyarakat, berbangsa, dan bernegara hukumnya adalah wajib.

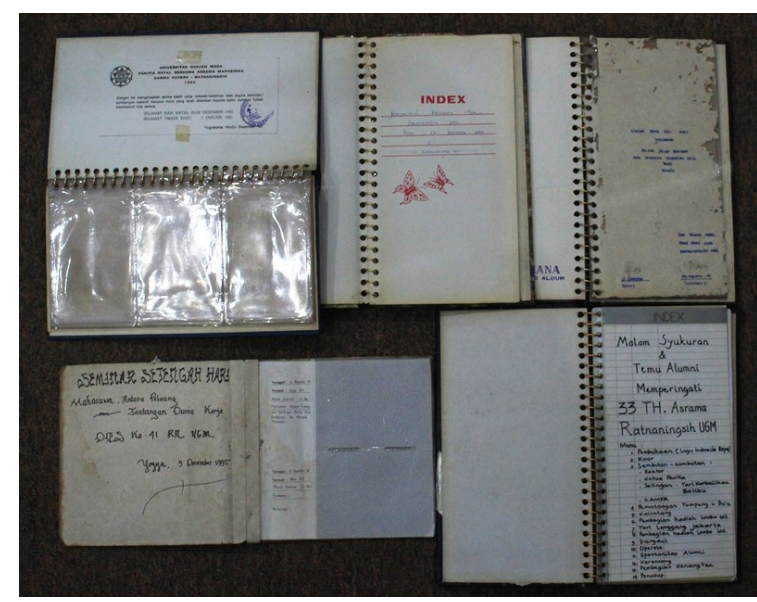

Gambar 2. Informasi dalam Album Foto KAMPR

Sumber: Dokumentasi Personal

Berikut beberapa tahapan dalam mengolah foto asrama Ratnaningsih meliputi:

1. Observasi. Observasi meliputi pengumpulan data dan informasi mengenai koleksi foto asrama Ratnaningsih, kondisi dan jumlah koleksi yang disimpan oleh Etnohistori.

2. Perencanaan dan persiapan. Perencanaan dan persiapan mengacu pada perencanaan kebutuhan sarana dan prasarana, serta SDM (mahasiswa) yang dibutuhkan.

3. Identifikasi. Identifikasi foto mengacu pada kartu identifikasi. 


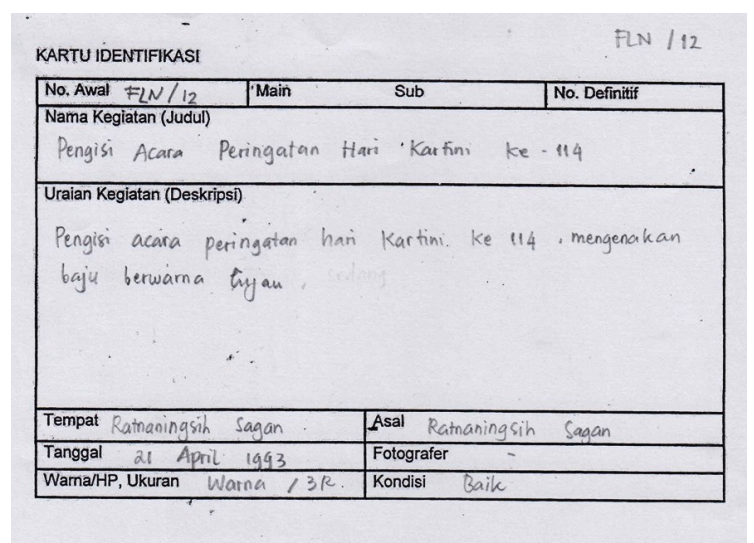

Gambar 3. Kartu Identifikasi

Sumber: Prodi Kearsipan SV UGM

- No. Awal: Berisi nama atau inisial dan nomor urut pengerjaan. Contoh: FLN/ 1, FLN/ 2, dst

- Main : Diisi berdasarkan masalah sesuai dengan skema klasifikasi.

- Sub main: Diisi berdasar sub masalah sesuai dengan skema klasifikasi.

- No. Definitif: Penomoran definitif diisi setelah pengelompokan dan manuver.

- Nama Kegiatan (Judul): Berisi judul kegiatan.

- Uraian kegiatan (deskripsi): Berisi uraian kegiatan.

- Tempat: Tempat berlangsungnya kegiatan atau peristiwa yang terdapat dalam foto.

- Tanggal: Tanggal foto

- Warna: Foto hitam putih atau berwarna

- Asal: Berasal dari instansi atau organisasi.

- Fotografer: Nama fotografer

- Kondisi: Diisi sesuai dengan kondisi foto

4. Pembuatan skema klasifikasi. Pembuatan skema berdasarkan pada masalah atau kegiatan secara sistematis dan logis, disusun berjenjang dengan tanda-tanda khusus sebagai kode yang merupakan pedoman penataan arsip (Barthos, 2005, p.6). Skema klasifikasi digunakan untuk mengisi main dan sub main pada kartu identifikasi.

5. Pengelompokan berdasar pada main dan sub-main, berdasar pada masalah dan tahun.

6. Penomoran dan penyimpanan foto dalam amplop kemudian pemberian nomor dan kode pada kartu identifikasi dan amplop.

7. Penataan dalam boks.

8. Pembuatan Finding aids (Registered, loose leaf dan katalog) ${ }^{4}$

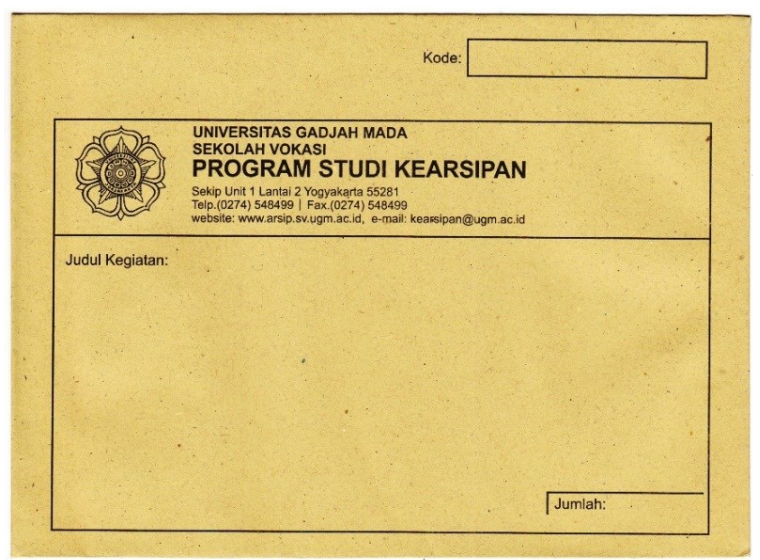

Gambar 4. Amplop untuk menyimpan foto (sarana prasarana praktikum) Sumber: Prodi Kearsipan SV UGM

\section{Digitalisasi dan Pameran Arsip}

Seiring dengan perkembangan Teknologi Informasi dan Komunikasi (TIK) yang semakin pesat, kerja pengarsipan pun dituntut untuk dapat memanfaatkan Teknologi Informasi dan Komunikasi untuk kepentingan praktis dengan mempertimbangkan aspek efisiensi dan fleksibilitas. Sistem kearsipan yang semula menggunakan sistem manual (berbasis konvensional) sedapat mungkin dapat beralih ke sistem elektronik. Namun, rasanya mustahil

${ }^{4}$ Prinsip fleksibilitas dan efisiensi dalam pertimbangan pemilihan model finding aids menjadi pilihan bagi lembaga kearsipan. Ketiga model finding aids model katalog, loose leaf, dan registered memiliki karakteristik masing-masing. Penjelasan mengenai ketiga model finding aids dapat di baca di Machmoed Effendhie, "Penilaian dan Model Finding Aids Arsip Foto: Sebuah Pengantar", dalam Khazanah, Volume 6,No. 1. Yogyakarta: Arsip Universitas Gadjah Mada. 2013. 
apabila sistem kearsipan berbasis konvensional tidak dibenahi terlebih dahulu sesuai dengan kaidah kearsipan, sebelum beralih ke dalam sistem elektronik.

Penyelamatan arsip saat ini mengacu pada bagaimana para pengguna dapat mengakses informasi arsip yang mampu diintegrasikan ke dalam teknologi. Salah satu metode penyelamatan arsip untuk tujuan pelestarian jangka panjang yaitu dengan digitalisasi. Digitalisasi menjadi mutlak dalam penyelamatan arsip dikarenakan perangkat media analog yang menjadi usang seiring dengan perkembangan teknologi serta ketersedian sparepart yang sulit ditemukan dan langka. Ditambah dengan biaya perawatan dan penyimpanan arsip akan menjadi lebih mahal. Oleh karena itu upaya penyelamatan arsip dengan digitalisasi menjadi urgensi yang wajib dilakukan. Secara konseptual, digitalisasi merupakan instrumen penting dalam proses melestarikan arsip (Sugiharto, 2011, p. 36-37). Digitalisasi adalah cara merubah arsip konvensional dalam berbagai bentuk dan media menjadi digital. Proses digitalisasi dapat menggunakan dua cara sesuai peralatan yang digunakan yaitu digitalisasi dengan pemindai atau scanner dan digitalisasi dengan kamera digital.

Dalam proses digitalisasi, beberapa aspek penting dalam memahami karakter fisik arsip antara lain (Effendhie, dkk, 2010):

a. Jenis arsip

Material arsip dapat berupa tulisan, teks atau naskah; arsip foto berupa gambar; sedangkan arsip kartografi berupa peta, denah, chart, desain, sketches, bagan, arsip kearsitekturan dan gambar teknik.

b. Ukuran

Arsip foto, arsip tekstual maupun arsip kartografi memiliki ukuran tersendiri. Biasanya ukuran arsip foto lebih kecil dari arsip tekstual dan arsip kartografi. Ukuran objek sangat penting karena akan menentukan jenis dan ukuran mesin pemindai.

c. Struktur

Susunan arsip dapat berwujud lembaran lepas atau lembaran jilid yang dapat berpengaruh pada tahap digitalisasi.

d. Warna

Tidak jarang sebuah warna mempunyai makna dan filosofi tersendiri. Jika demikian maka digitalisasi arsip perlu memperhatikan elemen warna yang terdapat pada arsip asli. Apabila warna merupakan informasi penting untuk mengapresiasi objek maka warna tidak boleh dimanipulasi. Hal ini penting karena teknologi alih media digital memungkinkan manipulasi itu. Selain itu, warna juga kan menentukan resolusi, tipe pemindaian dan kedalam bit dalam proses digitalisasi.

e. Usia

Usia arsip juga perlu diperhatikan. Arsip yang sudah tua harus ditangani secara hati-hati. Disamping faktor keunikan, arsip tua juga sering mengalami kerapuhan. Arsip semacam ini akan sangat berbahaya jika dialih mediakan dengan mesin scanner akan tetapi lebih aman jika menggunakan kamera digital. Aspek umur arsip perlu mendapat perhatian karena terkait dengan keselamatan arsip itu sediri.

Dengan pemahaman menyeluruh tentang karakter arsip maka akan berdampak pada proses dan hasil digitalisasi yang menentukan cara penanganan, alat pemindai, jenis format, dan resolusi. Selain itu, dibutuhkan aspek tambahan untuk menjamin hasil digitalisasi yang baik harus didukung oleh sarana dan peralatan yang standar antara lain scanner, Personal Computer dan software. Citra digital dapat disimpan dalam beberapa jenis format file. Pemilihan jenis format file 
tergantung dari tujuan penggunaanya. Citra digital untuk keperluan preservasi arsip (citra digital master) berbeda dengan format digital untuk akses dan penayangan pada halaman web. Dalam melakukan proses scanning, dianjurkan untuk hanya satu kali. Oleh karena itu dibutuhkan perencanaan yang matang. Diketahui sinar dalam scanner pada proses scanning memiliki daya perusak 4 kali lebih besar dari sinar fotokopi.

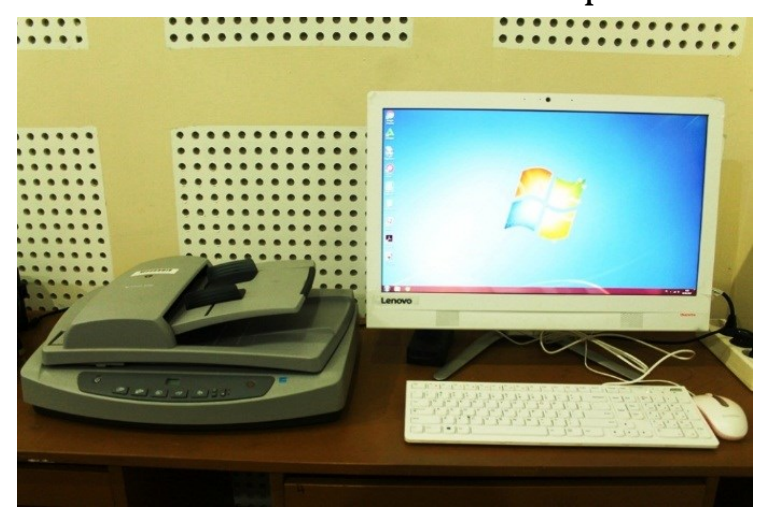

Gambar 4. Perangkat Komputer (All in One $P C)$ dan Scanner Laboratorium Arsip Audiovisual Prodi Kearsipan SV UGM Sumber: Dokumentasi Personal

putih). Untuk thumbnail menggunakan format JPEG sebesar 72 dpi RGB warna 8 bit (foto berwarna), 4 bit skala kelabu (foto hitam putih). Resolusi pemindaian arsip foto berbeda dengan arsip tekstual maupun arsip kartografi. Informasi mengenai warna dalam suatu citra digital tergantung pada jumlah warna atau tingkat degradasi kelabu yang dibawa oleh suatu pixel. Kemampuan membawa ini mengandung arti lingkup dinamika atau kedalaman bit (bit depth) dari pixel yang bersangkutan. ${ }^{5}$ Sebuah bit adalah unit penyimpan terkecil dalam sebuah komputer, Semakin besar lingkup dinamika atau kedalam bit akan semakin kecil nuansa perbedaan antar warna atau degradasi (Effendhie, dkk, 2010).

Hasil digitalisasi kemudian disimpan ke dalam media simpan. Media simpan citra digital dalam berbagai media (magnetik, optik dan solid state) akan sangat tergantung pada perubahan teknologi dan para produsen yang bergelut dengan teknologi dipastikan tidak menjamin bahwa media simpan yang diciptakan mampu bertahan dalam

\begin{tabular}{|c|l|l|l|}
\hline No & \multicolumn{1}{|c|}{ Tema Pameran } & Waktu Pelaksanaan & \multicolumn{1}{c|}{ Tempat } \\
\hline 1 & $\begin{array}{l}\text { Dolanan Jaman Biyen (Mainan } \\
\text { Jaman Dahulu) }\end{array}$ & $5-7$ Juli 2012 & Lobby Sekolah Vokasi UGM \\
\hline 2 & $\begin{array}{l}\text { Kampus Kerakyatan dalam } \\
\text { Lipatan Zaman }\end{array}$ & $12-14$ Maret 2015 & Taman Budaya Yogyakarta \\
\hline 3 & $\begin{array}{l}\text { Menyingkap Arsip Industri di } \\
\text { Yogyakarta }\end{array}$ & $13-15$ Mei 2016 & Benteng Vredeburg \\
\hline 4 & Rajut Karya Bhinneka & $28-30$ April 2017 & Benteng Vredeburg \\
\hline
\end{tabular}

Tabel 1. Pameran Arsip Program Studi Kearsipan SV UGM

Sumber: Program Studi Kearsipan SV UGM

Resolusi atau ukuran citra digital pada arsip foto untuk file master menggunakan format TIFF sebesar 600dpi, RGB warna 24 bit (foto berwarna), 8 bit skala kelabu (foto hitam putih). Untuk file akses menggunakan format TIFF sebesar 300dpi format TIFF sebesar 600dpi, RGB warna 24 bit (foto berwarna), 8 bit skala kelabu (foto hitam
5 Bi-tonal, dikenal juga sebagai line art atau black and white. Tipe ini sangat baik untuk pemindaian teks tercetak atau citra digital dengan kontras tinggi. Tipe skala kelabu (grey scale) dapat memberikan ruang lingkup degradasi kelabu dalam suatu citra digital dan lebih baik dari black and white, serta sangat cocok untuk dokumen dengan tone yang berkelanjutan dan negatif black and white. Tipe color menduplikasikan lingkup warna dari citra asli ke citra digital dengan lebih baik. 
jangka waktu yang lama. Media simpan juga ditentukan oleh kombinasi pemakaian hardware maupun software. Kumpulan hasil digitalisasi disebut sebagai database yang disimpan dalam server storage. Setiap file akan menerangkan format dan keaslian serta terkait dengan metadatanya.

Program Studi Kearsipan Sekolah Vokasi UGM melalui mata kuliah Eksibisi Arsip menjadi salah satu bagian terpenting dalam proses mensosialisasikan pentingnya arsip bagi kehidupan. Para mahasiswa dituntut untuk dapat merancang sebuah pameran arsip yang menjadi agenda tahunan rutin. Mahasiswa dibimbing dalam observasi dan riset sampai proses memamerkan

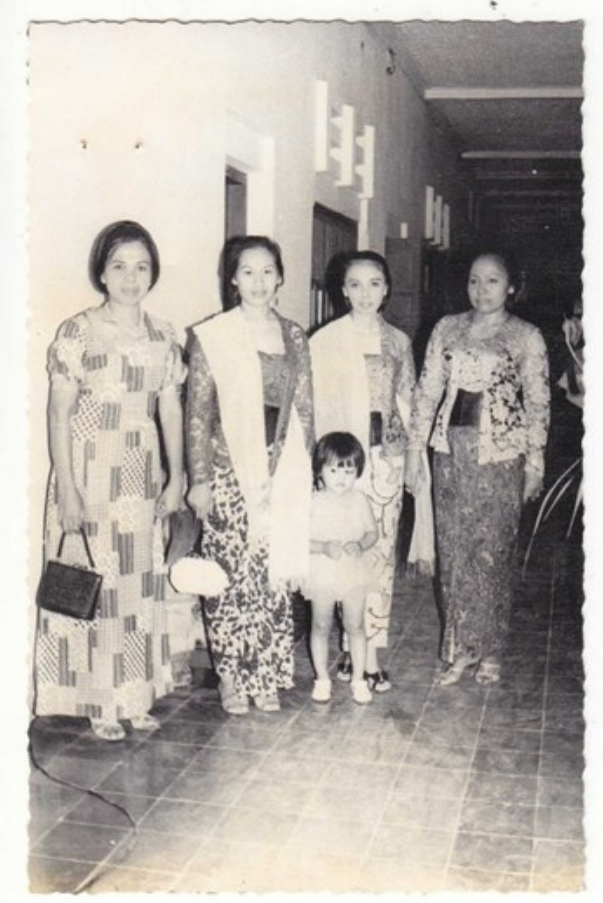

informasi mengenai tema yang dipamerkan. Program Studi Kearsipan memiliki misi untuk mengedukasi sekaligus sebagai bentuk promosi. Perencanaan untuk membuat pameran virtual sebagai sarana edukasi masyarakat menjadi penting dalam era teknologi informasi sekarang ini dan diharapkan di tahun 2018, program tersebut dapat terealisasikan.

\section{KESIMPULAN}

Arsip akan terkait dengan dimensi waktu. Kajian akademis yang berkaitan dengan arsip tentu memiliki benang merah yaitu informasi atau peristiwa di masa lampau. Organisasi Keluarga Asrama Mahasiswa Putri Ratnaningsih

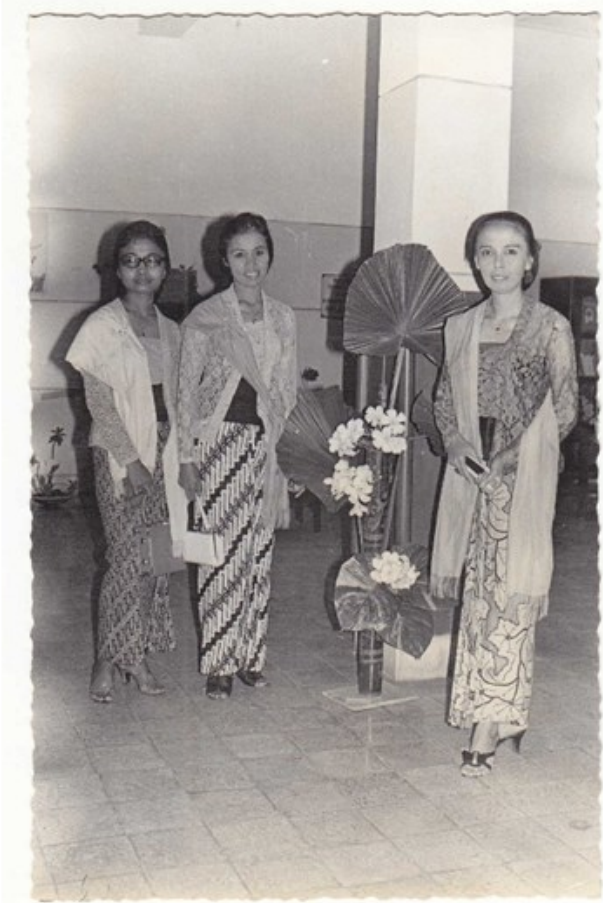

Gambar 5. Salah satu foto yang sudah dipindai dan dipamerkan dalam Pameran Arsip 2017 Prodi Kearsipan, SV UGM

arsip. Pameran arsip yang telah dilaksanakan oleh Program Studi Kearsipan sebanyak 4 (empat) kali.

Beberapa arsip foto kegiatan Asrama Ratnaningsih kemudian dipindai dan dicetak untuk dipajang dalam Pameran Arsip 2017. Dengan adanya pameran arsip, berbagai manfaat diberikan masyarakat dan Program Studi Kearsipan. Masyarakat memperoleh
(KAMPR) dengan berbagai aktivitas dan kegiatan organisasi di masa lampau secara aktual dapat dilihat melalui arsip yang diciptakannya. "Penghilangan" organisasi Keluarga Asrama Mahasiswa Putri Ratnaningsih (KAMPR) bukan berarti melenyapkan aktualitas yang ada, melainkan kenyataan baik berupa peristiwa akan turut serta jika rekaman sezaman sebagai recorded memory juga 
ikut terjaga dengan baik. Koleksi foto kegiatan organisasi Keluarga Asrama Mahasiswa Putri Ratnaningsih (KAMPR) merupakan warisan visual yang dapat dipergunakan untuk melihat gerakan sosial bercorak asrama. Foto sebagai hasil rekaman kehidupan sosial dapat menggambarkan moment tertentu. Oleh karena itu, informasi yang terkandung di dalam foto kemungkinan tidak terdapat dalam arsip lain yang menjadi dasar bahwa foto bernilai guna perlu untuk dijaga dan dilestarikan. Menjaga dan melestarikan arsip bukan perkara mudah apalagi arsip foto yang membutuhkan penanganan dan perhatian khusus.

Aktivitas interaktif mahasiswa yang berkaitan dengan pengolahan arsip bertujuan untuk menambah kemampuan dan keterampilan mahasiswa. Proses pembelajaran kognitif dan afektif akan menambah stimulus untuk meningkatkan intelektualitas mahasiswa dalam mengolah arsip foto. Mahasiswa belajar untuk menilai arsip dari sisi nilai kebuktian dan nilai informasi, sehingga kesadaran sejarah akan tumbuh. Hal itu menjadi penting agar arsip yang ditanganinya pun memiliki kualitas dan kualifikasi untuk dijaga dan dilestarikan sebagai memori bersama.

Proses digitalisasi merupakan upaya penyelamatan arsip khususnya arsip foto organisasi Keluarga Asrama Mahasiswa Putri Ratnaningsih (KAMPR), sehingga jejak organisasi asrama sebagai sebuah gerakan sosial dengan segala aktivitasnya akan tetap terjaga. Selain itu, sebagai sarana edukasi mengenai pentingnya arsip foto dalam berbagai kehidupan tampak pada banyaknya pameran arsip. Salah satunya adalah pameran arsip yang dilaksanakan oleh Program Studi Kearsipan SV UGM.

Mengutip Arthur Doughty seorang Dominion Archivist of Canada, 1904-1935 bahwa "Dari semua aset nasional, arsip adalah yang paling berharga. Mereka adalah pemberian dari satu generasi ke generasi yang lain, dan tingkat kepedulian kita terhadap arsip menandai tingkat peradaban kita"

\section{DAFTAR PUSTAKA}

Adhie Gesit Pambudi (2014). "Konteks, Konteks, Konteks! Aspek Fundamental Dalam Proses Pengolahan Arsip Foto". Jurnal Kearsipan, Volume ${ }^{3}$, No. 5. Pusat Pengkajian dan Pengembangan Sistem Kearsipan Arsip Nasional Republik Indonesia.

Anna Mariana (2014). "Menghidupkan Arsip, Mencipta Wacana. Pentingnya Arsip Untuk Gerakan Sosial”, Farah Wardani dan Yoshi fajar Kresno Murti. Arsipelago, Kerja Arsip dan Pengarsipan Seni Budaya di Indonesia. Yogyakarta: Indonesia Visual Art Archive (IVAA).

Arif Rahman Bramantya (2016). "Revolusi Mental, Gerakan Sadar Arsip dan Kesadaran Sejarah", dalam Revolusi Mental Bidang Kearsipan, ANRI Media Kearsipan Nasional, Edisi 70. Jakarta: Arsip Nasional Republik Indonesia.

Basir Barthos (2005). Manajemen Kearsipan. Jakarta: Bumi Aksara.

David Robert (1993). "Managing Records in Special Format", Judith Ellis (ed), in Keeping Archive. Melbourne: D.W Thorpe.

Dhani Sugiharto (2011). "Penyelamatan Arsip di Era Teknologi Digital”, dalam Peran Arsip dalam Membangun Karakter Bangsa, ANRI Media Kearsipan Nasional, Edisi 54. Jakarta: Arsip Nasional Republik Indonesia.

Fitria Agustina (2013). "Mengenal Persatuan Wanita Keluarga Universitas Gadjah Mada melalui Khazanah Arsip", Khazanah, Volume 6, No. 2. Yogyakarta: Arsip Universitas Gadjah Mada.

Helen P. Harrison (1997). Audiovisual Archives: A Practical Reader. Paris: UNESCO. 
Herman Setyawan (2014). "Preservasi Material Fotografi", Khazanah, Volume 7, No. 1. Yogyakarta: Arsip Universitas Gadjah Mada.

Klaus B. Hendriks (1984). The Preservation and Restoration of Photographic Materials in Archives and Libraries: A RAMP Study with Guidelines. Paris: UNESCO.

Machmoed Effendhie, Herman Setyawan (2012). Panduan Ringkas Pengelolaan Arsip Foto. Yogyakarta: Arsip Universitas Gadjah Mada.

Machmoed Effendhie, dkk (2010). Panduan Umum Digitalisasi Arsip. Yogyakarta: Arsip Universitas Gadjah Mada

Machmoed Effendhie (2013). "Penilaian dan Model Finding Aids Arsip Foto: Sebuah Pengantar", Khazanah, Volume 6, No. 1. Yogyakarta: Arsip Universitas Gadjah Mada.

Roeslan Abdulgani (1980). Arsip dan Sejarah. Jakarta: Arsip Nasional Republik Indonesia.

Undang-Undang No. 43 tahun 2009 Tentang Ketentuan-ketentuan Pokok Kearsipan.

Peraturan Kepala ANRI Nomor 23 Tahun 2011 tentang Pedoman Preservasi Arsip Statis.

Surat Edaran Kepala ANRI Nomor 1 Tahun 2017 tentang Peringatan Hari Kearsipan Ke-46 tahun 2017.

http://www.etnohistori.org/

https://www.ica.org/sites/default/files/ CBPS 2000 Guidelines ISAD\% 28G\%29 Second-edition EN.pdf 